\title{
IDENTIFICATION'S SOFTWARE MODULE OF THE DYNAMICS MATHEMATICAL MODELS OF MULTIDIMENSIONAL OBJECTS
}

\author{
T. Yu. Dorokhova ${ }^{1}$, E. Yu. Vyguzova ${ }^{2}$ \\ Departments: "Designing of Radio Electronic and Microprocessor Systems" (1), \\ "Foreign Languages" (2), TSTU, Tambov, Russia; \\ ele-vigozova@mail.ru
}

Keywords: controlled object; identification of mathematical models; mathematical modeling; software module.

Abstract: The article considers the identification problem of dynamics' mathematical models of multidimensional objects, the algorithm of parametrical identification is shown in the example model one zone of a multidimensional object as a double aperiodic link.

The considered algorithm of parametrical identification of dynamics' mathematical model of one multi-chamber dryer drum-band type section in the developed software module is implemented which allows to check and to assess the adequacy of the obtained model.

The mathematical modelling problem of the controlled object is one of the key components in the synthesis of automatic systems [1]. The most practical objects have multiple inputs and multiple outputs, it means they belong to the class of multidimensional (MIMO - Multiple Input Multiple Output), so the identification problem of the dynamics mathematical models of MIMO-objects is relevant.

The identification problem is formulated as follows: according to the results of the measured values of input and output variables of the object should be obtained are optimal in some sense or the largest permissible error model suitable for the solution of management tasks $[3,6]$. The General identification problem of dynamic model of the controlled object can be divided into a number of specific tasks, such as:

- identification of the model structure;

- estimation of model parameters;

- checking the adequacy of the obtained model.

For the identification of the model structure we will consider the simplified scheme of multidimensional object (Fig. 1).

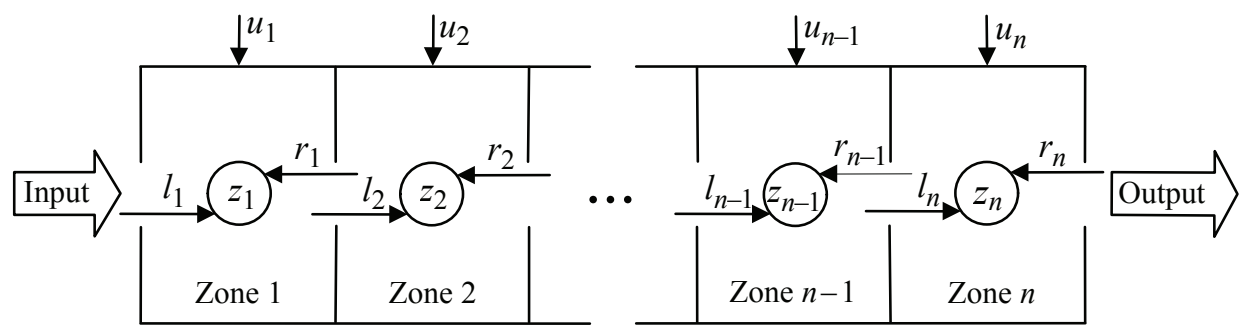

Fig. 1. The simplified scheme of multidimensional object 
On this scheme: $z_{i}, i=\overline{1, n}$ - phase coordinate $i$-zone's; $u_{i}$ - the operating influence $l_{i}, r_{i}$ - the revolting influences from the next zones at the left and from the right.

Based on constructive and technological reasons each zone is considered as the local multistage object with the concentrated parameters described by system of the differential equations with explosive right part [2]. The $i$-zone's model is written as:

$$
M_{i}: \dot{z}_{i}= \begin{cases}A_{i}^{1} z_{i}^{1}(t)+B_{i}^{1} u_{i}^{1}(t)+C_{i}^{1} l_{i}^{1}(t)+D_{i}^{1} r_{i}^{1}(t), & z_{i}^{1} \in\left[z_{0}^{1}, z_{\mathrm{K}}^{1}\right) ; \\ A_{i}^{2} z_{i}^{2}(t)+B_{i}^{2} u_{i}^{2}(t)+C_{i}^{2} l_{i}^{2}(t)+D_{i}^{2} r_{i}^{2}(t), & z_{i}^{2} \in\left[z_{0}^{2}, z_{\mathrm{K}}^{2}\right) ; \\ \cdots & \cdots \\ A_{i}^{m_{i}} z_{i}^{m_{i}}(t)+B_{i}^{m_{i}} u_{i}^{m_{i}}(t)+C_{i}^{m_{i}} l_{i}^{m_{i}}(t)+D_{i}^{m_{i}} r_{i}^{m_{i}}(t), & z_{i}^{m_{i}} \in\left[z_{0}^{m_{i}}, z_{\mathrm{K}}^{m_{i}}\right],\end{cases}
$$

where $A_{i}^{j}, B_{i}^{j}, C_{i}^{j}, D_{i}^{j}, j=\overline{1, m}_{i}, i=\overline{1, n}$ - are the matrixes of parameters for $j$-stage of $i$-zone; $z_{i}^{j}$ - a vector of phase coordinates; $z_{i 0}^{j}, z_{i \mathrm{\kappa}}^{j}$ - the $j$-stage border.

The dynamics of all objects can be presented as a set of zone's models

$$
M=\left\{M_{1}, M_{2}, \ldots, M_{n}\right\},
$$

where $M_{i}, i=\overline{1, n}$ - a model of $i$-zone.

Each stage in (1) can be presented to one of dynamics basic models [4]:

- aperiodic link (A);

- double integrator (DI);

- real double integrator $(\mathrm{RDI})$;

- double aperiodic link (DA), etc.

The experiment on real object is made to definite the types of zone's models, number of stages and an assessment of parameters. As a result of the solution of structural identification problem optimum structures of dynamics models of MIMO object zones are allocated, one of the main choice criteria is the minimum of the maximum value of an absolute error of model.

The model parameters identification is the following stage after carrying out structural identification. Let's consider algorithm of parametrical identification on the example of model of one zone of multidimensional object in the form of a double aperiodic link:

$$
\left\{\begin{array}{l}
\dot{z}_{1}=z_{2}(t) \\
\dot{z}_{2}=a_{1} z_{1}(t)+a_{2} z_{2}(t)+b u(t)+c l(t)+d r(t) .
\end{array}\right.
$$

The parametrical identification algorithm of dynamics model of one zone of multidimensional object consists of the following stages:

1. A choice of basic data for identification (for the set type of model six values of the phase coordinates operating and the revolting influences in different time points get out):

$$
z_{1}^{i}(t), z_{2}^{i}(t), u^{i}(t), l^{i}(t), \quad r^{i}(t), \quad i=\overline{1,6} .
$$

2. The solution of the equations system

$$
\left\{\begin{array}{l}
K_{0} z_{1}^{i}(t)+K_{1} z_{2}^{i}(t)+K_{2} u^{i}(t)+K_{3} l^{i}(t)+K_{4} r^{i}(t)=z_{1}^{i+1}(t) ; \\
K_{5} z_{1}^{i}(t)+K_{6} z_{2}^{i}(t)+K_{7} u^{i}(t)+K_{8} l^{i}(t)+K_{9} r^{i}(t)=z_{2}^{i+1}(t) .
\end{array}\right.
$$


3. The calculation of dynamics model parameters:

$$
a_{1}=\frac{K_{5}}{K_{1}} ; \quad a_{2}=\frac{K_{6}-K_{0}}{K_{1}} ; \quad b=\frac{K_{7}}{K_{1}} ; \quad c=\frac{K_{8}}{K_{1}} ; \quad d=\frac{K_{9}}{K_{1}} .
$$

4. Checking the adequacy of the obtained model. To check the adequacy of the obtained model imitating modeling is carried out. The values of phase coordinates are calculated by the formulas:

$$
\left\{\begin{array}{l}
Z_{1}^{\mathrm{m}}(i+1)=F_{1} Z_{1}^{\mathrm{m}}(i)+G_{1} Z_{2}^{\mathrm{m}}(i)+H_{1} u(i)+V_{1} l(i)+W_{1} r(i) ; \\
Z_{2}^{\mathrm{m}}(i+1)=F_{2} Z_{1}^{\mathrm{m}}(i)+G_{2} Z_{2}^{\mathrm{m}}(i)+H_{2} u(i)+V_{2} l(i)+W_{2} r(i),
\end{array}\right.
$$

where

$$
\begin{array}{clc}
\lambda_{1}=\frac{a_{2}}{2}+\sqrt{\frac{a_{2}^{2}}{4}+a_{1}} ; \quad \lambda_{2}=\frac{a_{2}}{2}-\sqrt{\frac{a_{2}^{2}}{4}+a_{1}} ; & F_{1}=\frac{\lambda_{1} \mathrm{e}^{\lambda_{2} \delta t}-\lambda_{2} \mathrm{e}^{\lambda_{1} \delta t}}{\lambda_{1}-\lambda_{2}} ; \\
F_{2}=\frac{a_{1}\left(\mathrm{e}^{\lambda_{1} \delta t}-\mathrm{e}^{\lambda_{2} \delta t}\right)}{\lambda_{1}-\lambda_{2}} ; \quad G_{1}=\frac{\mathrm{e}^{\lambda_{1} \delta t}-\mathrm{e}^{\lambda_{2} \delta t}}{\lambda_{1}-\lambda_{2}} ; & G_{2}=\frac{\lambda_{1} \mathrm{e}^{\lambda_{1} \delta t}-\lambda_{2} \mathrm{e}^{\lambda_{2} \delta t}}{\lambda_{1}-\lambda_{2}} ; \\
H_{1}=\frac{b}{\lambda_{1}-\lambda_{2}} \frac{\lambda_{2} \mathrm{e}^{\lambda_{1} \delta t}-\lambda_{1} \mathrm{e}^{\lambda_{2} \delta t}-\lambda_{2}+\lambda_{1}}{\lambda_{1} \lambda_{2}} ; & H_{2}=\frac{b\left(\mathrm{e}^{\lambda_{1} \delta t}-\mathrm{e}^{\lambda_{2} \delta t}\right)}{\lambda_{1}-\lambda_{2}} ; \\
V_{1}=\frac{c}{\lambda_{1}-\lambda_{2}} \frac{\lambda_{2} \mathrm{e}^{\lambda_{1} \delta t}-\lambda_{1} \mathrm{e}^{\lambda_{2} \delta t}-\lambda_{2}+\lambda_{1}}{\lambda_{1} \lambda_{2}} ; & V_{2}=\frac{c\left(\mathrm{e}^{\lambda_{1} \delta t}-\mathrm{e}^{\lambda_{2} \delta t}\right)}{\lambda_{1}-\lambda_{2}} ; \\
W_{1}=\frac{d}{\lambda_{1}-\lambda_{2}} \frac{\lambda_{2} \mathrm{e}^{\lambda_{1} \delta t}-\lambda_{1} \mathrm{e}^{\lambda_{2} t}-\lambda_{2}+\lambda_{1}}{\lambda_{1} \lambda_{2}} ; & W_{2}=\frac{d\left(\mathrm{e}^{\lambda_{1} \delta t}-\mathrm{e}^{\lambda_{2} \delta t}\right)}{\lambda_{1}-\lambda_{2}}
\end{array}
$$

According to the result of calculation are plotted phase coordinates and calculated the absolute error, based on the value which a conclusion about the adequacy of the obtained dynamics model.

The program module in MathCAD system for realization above considered algorithm of identification is developed. As an example we will consider the mathematical dynamics model identification of one multi-chamber dryer drum-band type section $[5,7]$.

The basic data for dynamics model identification of multi-chamber dryer drumband type section are given in the Table 1 .

The results of mathematical dynamics model identification of multi-chamber dryer drum-band type section and the check of its adequacy are given in the figure 2 .

Table 1

Basic data for identification

\begin{tabular}{c|c|c|c|c|c|c}
\hline № & $T$ & $z_{1}(t)$ & $z_{2}(t)$ & $l(t)$ & $r(t)$ & $u(t)$ \\
\hline 1 & 0 & 20,0 & 0 & 0 & 0 & \\
2 & 2 & 27,4 & 4,626866 & $-2,1$ & $-0,1$ & \\
3 & 4 & 36,6 & 4,328358 & $-3,2$ & 0 & 100 \\
4 & 6 & 44,0 & 3,283582 & $-2,9$ & 0 & \\
5 & 8 & 49,9 & 2,686567 & $-3,0$ & $-0,1$ & \\
6 & 10 & 54,1 & 1,940299 & $-2,6$ & 0,3 & \\
\hline
\end{tabular}




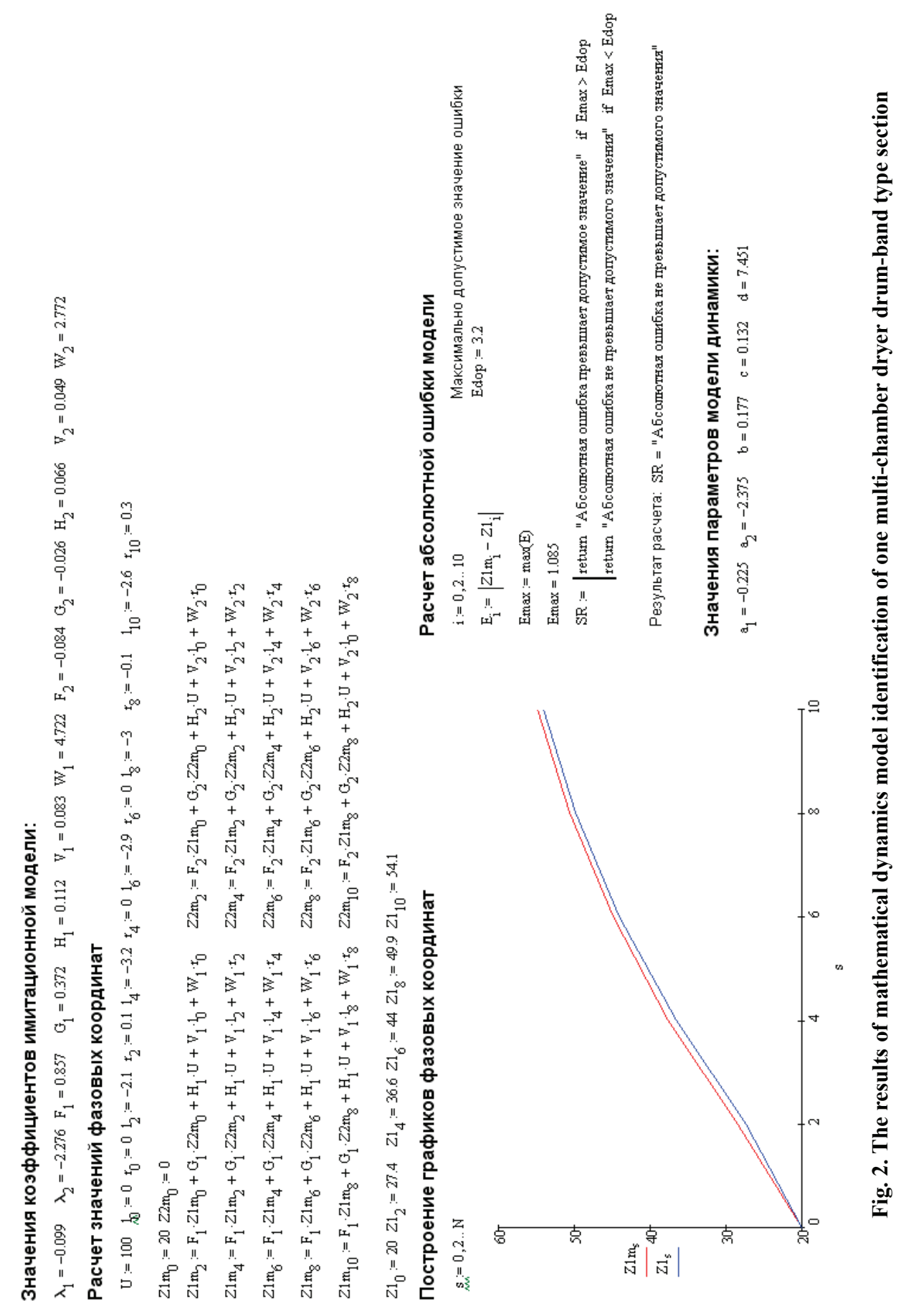


By the results of the software module operation it is possible to draw a conclusion that the obtained dynamics model is adequate as the absolute error of model doesn't exceed accepted value.

\title{
References
}

1. Starikov A.V. [Parametric identification of linear static controlled objects], Vestnik Samarskogo gosudarstvennogo tekhnicheskogo universiteta [Bulletin of the Samara State Technical University], 2004, no. 27, pp. 74-77. (In Russ.)

2. Bessonov A.N., Zagashvili Yu.V., Markelov A.S. Metody i sredstva identifikatsii dinamicheskikh ob"ektov [Methods and means of dynamic objects identification], Leningrad: Energoatomizdat, 1989, 300 p. (In Russ.)

3. Muromtsev D.Yu. Metody $i$ algoritmy sinteza energosberegayushchego upravleniya tekhnologicheskimi ob"ektami [Methods and synthesis algorithms of energy saving management of technological objects], Tambov, Moscow, St. Petersburg, Baku; Vienna: Nobelistika, 2005, 202 p. (In Russ.)

4. Muromtsev Yu.L., Orlova L.P. Mikroprotsessornye sistemy energosberegayushchego upravleniya [Microprocessor systems of energy saving management], Tambov: Izdatel'stvo Tambovskogo gosudarstvennogo universiteta, 2001, 80 p. (In Russ.)

5. Gribkov, A.N. [Management information system of the dynamic modes in multisection drying installations], Informatika $i$ sistemy upravleniya [Informatics and control systems], 2009, no. 2(20), pp. 123-129. (In Russ.)

6. Gribkov A.N., Kurkin A.I. [Identification of mathematical models of a drum dryer's dynamics on the set of States of the operation], Voprosy sovremennoi nauki $i$ praktiki. Universitet imeni V.I. Vernadskogo [Problems of Contemporary Science and Practice. Vernadsky University], 2014, special issue (52), pp. 32-36. (In Russ., Abstract in Eng.)

7. Muromtsev D.Yu., Gribkov A.N., Churikov A.A., Pasechnikov I.I. [Methodological aspects of building software-analytical complex design of energyefficient control systems], Transactions of the Tambov State Technical University, 2015, vol. 21, no. 4, pp. 542-547. doi: 10.17277/vestnik.2015.04.pp.542-547 (In Russ., Abstract in Eng.)

\section{Программный модуль идентификации математических моделей динамики многомерных объектов}

\author{
Т. Ю. Дорохова ${ }^{1}$, Е. Ю. Выгузова ${ }^{2}$
}

Кафедры: «Конструирование радиоэлектронных и микропроиессорных систем» (1), «Иностранные языки» (2), ФГБОУ ВО «ТГТУ», г. Тамбов, Россия; ele-vigozova@mail.ru

Ключевые слова: идентификация математических моделей; математическое моделирование; объект управления; программный модуль.

Аннотация: Рассмотрена проблема идентификации динамики математических моделей многомерных объектов, где алгоритм параметрической идентификации показан на примере модели одной зоны многомерного объекта в виде двойного апериодического звена.

Реализуется рассматриваемый алгоритм параметрической идентификации математической модели динамики одной секции многокамерной сушильной установки вальце-ленточного типа в разработанном программном модуле, который позволяет производить проверку и давать оценку адекватности полученной модели. 


\section{Список литературь}

1. Стариков, А. В. Параметрическая идентификация линейных статических объектов управления / А. В. Стариков // Вестн. Самар. гос. техн. университета. 2004. - № 27. - С. $74-77$.

2. Бессонов, А.Н. Методы и средства идентификации динамических объектов / А. Н. Бессонов, Ю. В. Загашвили, А. С. Маркелов. - Л. : Энергоатомиздат, 1989. - 300 с.

3. Муромцев, Д. Ю. Методы и алгоритмы синтеза энергосберегающего управления технологическими объектами : монография / Д. Ю. Муромцев. Тамбов ; М. ; СПб. ; Баку ; Вена : Нобелистика, 2005. - 202 с.

4. Муромцев, Ю. Л. Микропроцессорные системы энергосберегающего управления : учеб. пособие / Ю. Л. Муромцев, Л. П. Орлова. - Тамбов : Изд-во Тамб. гос. техн. ун-та, 2001. -80 с.

5. Грибков, А. Н. Информационно-управляющая система динамическими режимами в многосекционных сушильных установках / А. Н. Грибков // Информатика и системы управления. - 2009. - № 2(20). - 2009. - С. 123 - 129.

6. Грибков, А. Н. Идентификация математических моделей динамики барабанной сушильной установки на множестве состояний функционирования / А. Н. Грибков, И. А. Куркин // Вопр. соврем. науки и практики. Университет им. В. И. Вернадского. - 2014. - Спец. вып. (52). - С. 32 - 36.

7. Методологические аспекты построения программно-аналитического комплекса проектирования систем энергосберегающего управления / Д. Ю. Муромцев [и др.] // Вестн. Тамб. гос. техн. ун-та. - 2015. - Т. 21, № 4. - С. 542 - 547. doi: 10.17277/vestnik.2015.04.pp.542-547

\section{Programmmodul der Identifizierung der mathematischen Modelle der Dynamik der multidimensionalen Objekte}

Zusammenfassung: Es ist das Problem der Identifizierung der Dynamik der mathematischen Modelle der multidimensionalen Objekte betrachtet. Es ist der Algorithmus der parametrischen Identifizierung am Beispiel des Modells einer Zone des multidimensionalen Objektes (der mehrzelligen Trockenanlage des Walzebandtyps) in Form des doppelten aperiodischen Gliedes dargelegt.

\section{Module logiciel de l'identification des modèles mathématiques de la dynamique des objets multidimensionnels}

Résumé: Est considéré le problème de l'identification de la dynamique des modèles mathématiques des objets multidimensionnels. Est présenté l'algorithme de l'identification paramétrique à l'exemple du modèle d'une zone de l'objet multidimensionnel (installation multicaméra du séchage du type rectifieuse à bande) sous la forme d'un double maillon apériodique.

Авторы: Дорохова Татьяна Юрьевна - кандидат педагогических наук, доцент кафедры «Конструирование радиоэлектронных и микропроцессорных систем»; Выгузова Елена Юрьевна - кандидат филологических наук, доцент кафедры «Иностранные языки», ФГБОУ ВО «ТГТУ», г. Тамбов, Россия.

Рецензент: Селиванова Зоя Михайловна - доктор технических наук, профессор кафедры «Конструирование радиоэлектронных и микропроцессорных систем», ФГБОУ ВО «ТГТУ», г. Тамбов, Россия. 